\title{
TOURISM, AGRICULTURE AND VILLAGE DEVELOPMENT \\ - STRATEGIC OBJECTIVES OF ECONOMIC DEVELOPMENT \\ OF KRUSEVAC
}

\author{
Violeta Babić ${ }^{1}$ \\ Valentina Simić ${ }^{2}$
}

DOI: https://doi.org/10.31410/tmt.2019.441

\begin{abstract}
Social, economic and infrastructural development as well as environmental development are the priorities of the Sustainable Development Strategy of the City of Krusevac for the period 2010-2020. Economic development has four strategic goals - supporting local economy and entrepreneurship, attracting investment, developing agriculture and villages - rural development and tourism development. Rural development, which implies the development of agriculture and rural areas, is one of the goals which realization will contribute to the faster economic development of the city. The City Administration, line ministries, local partners and farmers themselves contribute to the development of agriculture and rural areas by implementing activities related to increasing the productivity and competitiveness of agriculture and the processing sector along with applying new knowledge, improving land and land structure and diversifying rural activities. The integration of agriculture and tourism can significantly contribute to the economic development of the City of Krusevac and the entire Rasina District, too. The City of Krusevac has recognized advanced agricultural and tourism potentials that can be utilized for faster economic development; therefore, activities to develop and connect them are undertaken by the city.
\end{abstract}

Keywords: agriculture, village, tourism, City of Krusevac.

\section{INTRODUCTION}

$\mathrm{T}^{\mathrm{h}}$ he Rasina District and the City of Krusevac have an exceptional geographical position, favorable climatic characteristics and rich cultural and historical heritage. They are located in the fertile basin of the two rivers Morava and Rasina, at the crossroads of the Balkan Peninsula and the European Union. The characteristics of land, relief and climate favor the development of various agricultural branches, and agriculture itself is a traditional economic activity concerned by a large part of the population in this area. Tradition, cultural and historical heritage are enormous potential for the development of different types of tourism. The development of rural tourism based on agricultural potentials and the integration of agriculture and tourist facilities, are strategic goals of the city economic development which presents one of the priorities of Sustainable Development Strategy of the City of Krusevac. Agricultural potentials significant contribution to the economic development of the city and the whole Rasina District, has been recognized; therefore, they are advanced and improved through various activities in order to make their contribution to economic development larger, completer and more significant.

Priority of Strategy for sustainable development of the city of Krusevac is economic development, and strategic objectives are supporting of economy and entrepreneurship, attracting investments, development of agriculture, rural areas and tourism. The research subjects of this paper represent actions and measures that contribute to the development of agriculture and rural as well as development of tourism, with the aim to pointing out their contribution to the overall economic development of the city of Krusevac and Rasina District.

\footnotetext{
1 Faculty of Agriculture, Krusevac, University of Nis, Kosanciceva 4, Krusevac, Serbia

2 Faculty of Applied Sciences, Nis, University “Union - Nikola Tesla”, Belgrade, Obrenoviceva 46, Nis, Serbia
} 


\section{RASINA DISTRICT AND KRUSEVAC MUNICIPALITY - NATURAL AND HUMAN RESOURCES}

Rasina District covers an area of 2,668 $\mathrm{km}^{2}$, which is $3.34 \%$ of the total area of the Republic of Serbia, and has 241,999 inhabitants in six municipalities (Krusevac, Aleksandrovac, Trstenik, Brus, Varvarin and Cicevac). The district is located at an altitude of $250-2017 \mathrm{~m}$, in the fertile basin of rivers Rasina, Južna Morava, Zapadna Morava and Velika Morava, and it is surrounded by mountain ranges of Kopaonik, Jastrebac, Goč, Željin and Gledićke Planinine. The Rasina District is characterized mostly by hilly relief, while in the valleys of rivers, there are fertile lowland areas. The average altitude of the district is $300 \mathrm{~m}$, with $35 \%$ of the surface covered with forests, significantly contributed by Jastrebac, which is the most wooded mountain in the Balkans. The municipality areas of Aleksandrovac, Brus and Trstenik extend on the slopes of mountains Goč, Željin and Kopaonik, while the of Cicevac and Varvarin municipalities are located in the valleys of Južna Morava, Zapadna Morava and Velika Morava, where fertile land is the mainstay of agricultural development. The climate in the Rasina District is moderately continental, with warm summers, cold and moderate winters, while spring and autumn last relatively short. Wind Košava blows in the river Morava valley but of lower intensity than in the Danube region. The lowest temperatures appear in January and the highest in July, and the average air temperature is $11^{\circ} \mathrm{C}$. (RPK)

The Rasina District geographical and climatic characteristics are conducive to the development of all agricultural branches with significant contribution of Agricultural Fair, which is held annually in Krusevac. This Fair is the most significant agribusiness event of the Rasina District, representing livestock feed producers, seed products producers, agricultural machinery and equipment, wines, brandy, honey and handicraft products manufacturers, banks and insurance companies.

The Rasina District, as well as the City of Krusevac itself, have significant cultural and historical sites, which makes this part of Serbia an extremely important place on the tourist map. These are the archeological park „Lazarev grad”, Lazarica Church, National Museum, monument to Prince Lazar, Donžon tower, Prince's palace, Milić of Mačva Gallery, Mosaic hall, Monument to the Kosovo Heroes, Simić House, Wall painting „Obretenje Lazarevo”, Warriors Monument 1912 -1918, St. George's Church, Sculpture „Mother Serbia and Mother Greece”, Memorial Park „Slobodište”.

Region's rich tourist offer is presented by: Jastrebac - the highest mountain near Krusevac, mountain Kopaonik known as the „Roof of Serbia”, Ribarska Banja - one of the oldest spas in the southeastern Balkans, an oasis of clean mountain air and healthy food, and Bela Voda, famous for its natural resources - white stone sandstone and mineral water springs. Parts of Serbian spiritual heritage receiving great attention are: the mountain Mojsinjske planine, known as the „Serbian little Sveta Gora”, the Church of the Protection of the Blessed Virgin Mary on river Rasina and the Church of St. George in the center of Krusevac, as well as the monasteries Drenča, Naupar, Mrzenica, Ljubostinja, Rudenica, Sveti Roman, Veluće and the monastery of the Holy Virgin Cover.

Krusevac, Trstenik, Brus and Aleksandrovac tourist organizations actively contribute to bringing the tourist offer closer to potential guests, tourists and visitors. According to geographical location, favorable climatic characteristics and extremely rich historical and cultural heritage, this region has all the preconditions for economic development. 
Population growth and its dynamics are a key factor in development. Population growth of the world population is conditioned only by natural growth, while population growth in one country depends not only on natural growth but also on population migration.

According to the 2002 census, there were 259,441 inhabitants in 296 settlements in the Rasina District, and 241,999 according to the 2011 census. The population decline has been noticeable in the last two decades (Table 1). According to the 2011 census, the population of Rasina District made up 3.36\% of the total population of the Republic of Serbia, and according to the 2002 census this indicator was at the level of $3.46 \%$, which also indicates a decrease in the population of Rasina District. (RSZ a))

According to the 2011 census, there were 2,487,886 households in Serbia, with an average of 2.88 members per household. There were 77,270 households in the Rasina District, which is an average of 3.13 members per household. (RSZ a)). The tendency of population decline in Rasina District is followed by the tendency of decrease in the number of households, except for the City of Krusevac itself, recording an increase in the number of households, which is shown in the following table.

Table 1. Demographic statistics by municipalities of Rasina District, in the period 2001-2013

\begin{tabular}{|c|c|c|c|c|c|c|c|c|c|c|}
\hline \multirow[t]{2}{*}{$\begin{array}{l}\text { Indicator } \\
\text { Year } \\
\text { Municipality }\end{array}$} & \multicolumn{2}{|c|}{$\begin{array}{l}\text { Number of } \\
\text { households }\end{array}$} & \multicolumn{2}{|c|}{ Population } & \multicolumn{2}{|c|}{ Birth rate } & \multicolumn{2}{|c|}{ Mortality } & \multicolumn{2}{|c|}{$\begin{array}{l}\text { Natural } \\
\text { population } \\
\text { growth }\end{array}$} \\
\hline & 2002 & 2011. & 2002. & 2011. & 2001. & 2013. & 2001. & 2013. & 2001. & 2013. \\
\hline Aleksandrovac & 8.789 & 8.146 & 29.389 & 26.522 & 9,0 & 6,5 & 9,0 & 15,7 & $-3,4$ & $-9,1$ \\
\hline Brus & 5.840 & 5.320 & 18.764 & 16.317 & 7,7 & 7,7 & 7,7 & 16,1 & $-4,3$ & $-8,4$ \\
\hline Varvarin & 5.998 & 5.544 & 20.122 & 17.966 & 9,5 & 5,6 & 9,5 & 17,9 & $-5,9$ & $-12,3$ \\
\hline Trstenik & 15.600 & 14.342 & 49.043 & 42.966 & 8,1 & 6,8 & 8,1 & 16,3 & $-3,9$ & $-9,5$ \\
\hline Kruševac & 40.188 & 40.947 & 131.368 & 128.752 & 10,6 & 8,5 & 10,6 & 14,4 & $-1,8$ & $-5,8$ \\
\hline Ćićevac & 3.332 & 2.971 & 10.755 & 9.476 & 10,0 & 5,7 & 10,0 & 14,5 & $-5,0$ & $-8,8$ \\
\hline $\begin{array}{l}\text { Rasina District } \\
\text { (in total) }\end{array}$ & 79.747 & 77.270 & 259.441 & 241.999 & 9,6 & 7,6 & 9,6 & 15,2 & $-3,0$ & $-7,6$ \\
\hline
\end{tabular}

Source: NBS a), b)

Population density reflects the spatial distribution of the population and is important for considering the spatial frameworks of labor supply and spatial differentiation of the national market, which is important for the development of both social and economic activities. Population density in the Rasina District is slightly below the population density level in Serbia and amounts to 89 inhabitants per square kilometer. Krusevac is the most densely populated city presenting the administrative, educational and cultural center of the region, and the least populated is the Brus municipality, which is a mountainous area in relief.

The birth rate tends to decline in the Rasina District but in recent years, birth rate has slightly increased or remained at the same level, so as the result, the district birth rate has remained at the same level in recent years. The highest birth rate is in the Krusevac municipality and the lowest one is in the municipalities of Varvarin and Cicevac.

Generally, the population of Serbia is in the process of aging, and there are the same tendencies in the Rasina District. The number of young and middle-aged population is declining and the number of the old population is increasing. The average age of the total population in Serbia is constantly increasing - in 2011 it was 42.2 years, in 2014 it was 42.6 years, and in 2018 it was 
43.2 years, which places Serbs among the oldest nations in the world. The average age of the population in Rasina District was 45 years in 2018 (RZS c)).

Human capital is an important factor in the development of the national economy. Macroeconomic aggregates of production and consumption are closely related to human capital - through labor and its employment, occupation, activity, labor status, but also through the relationship between economic activity and inactivity in the total population. Demographic aging is intense in the Republic of Serbia, and the trend is expected to continue in the future. The workforce is reducing, its age structure is deteriorating, which is reflected in both labor productivity and then economic growth. At the same time, the number of pensioners is growing among the economically inactive population and the ratio between the number of employees whose earnings funded pensions and the number of those receiving them is deteriorating. The financial pressure of the population social protection systems - the pension and the health system, increases in such circumstances. These trends are also visible in the economic structure of Rasina District population.

Table 2. Employment and unemployment by Rasina District municipalities, 2011 and 2018

\begin{tabular}{|l|c|c|c|c|c|c|}
\hline \multirow{2}{*}{ Municipality } & \multicolumn{4}{|c|}{2011.} & \multicolumn{2}{c|}{2018.} \\
\cline { 2 - 7 } & $\begin{array}{c}\text { Total } \\
\text { population }\end{array}$ & $\begin{array}{c}\text { Economically } \\
\text { active }\end{array}$ & $\begin{array}{c}\text { Unemployed } \\
\text { persons }\end{array}$ & $\begin{array}{c}\text { Unemployment } \\
\text { rate }\end{array}$ & $\begin{array}{c}\text { Employed } \\
\text { persons }\end{array}$ & $\begin{array}{c}\text { Unemployed } \\
\text { persons }\end{array}$ \\
\hline $\begin{array}{l}\text { Rasina District } \\
\text { (in total) }\end{array}$ & 241.999 & 97.385 & 23.387 & 24,0 & 56.499 & 22.125 \\
\hline Aleksandrovac & 26.522 & 10.460 & 1.576 & 15,1 & 6.433 & 2.093 \\
\hline Brus & 16.317 & 7.324 & 1.005 & 13,7 & 3.761 & 1.852 \\
\hline Varvarin & 17.966 & 6.645 & 825 & 12,4 & 3.298 & 964 \\
\hline Kruševac & 128.752 & 51.299 & 15.419 & 30,1 & 31.611 & 11.917 \\
\hline Trstenik & 42.966 & 17.991 & 3.767 & 20,9 & 9.121 & 4.421 \\
\hline Ćićevac & 9.476 & 3.666 & 795 & 21,7 & 2.273 & 878 \\
\hline
\end{tabular}

Source: NBS d), NZS

There were 23.387 unemployed persons at the Rasina District at the end of 2011. and 22.125 at the end of 2018. according to the records of the National Employment Service. The following table shows that the total number of unemployed persons in the Rasina District has decreased and the increase in the number of employees in the city of Krusevac contributed to this, while an increase in the number of unemployed persons was recorded in all other municipalities of the Rasina District.

If we compare the employment, unemployment, activity and inactivity rates in the Republic of Serbia and the Rasina District, in 2018, we will see that in the Rasina District the employment and activity rates are lower and the unemployment and inactivity rates are higher (Table 3).

Table 3. Employment rate, unemployment rate, activity and inactivity rates in the Republic of Serbia and the Rasina District in 2018 (\%)

\begin{tabular}{|c|c|c|c|c|}
\cline { 2 - 5 } \multicolumn{1}{c|}{} & Employment rate & Unemployment rate & Activity rate & Inactivity rate \\
\hline Republic of Serbia & 47,6 & 12,7 & 54,5 & 45,5 \\
\hline Rasina District & 44,4 & 16,1 & 52,9 & 47,1 \\
\hline
\end{tabular}

Source: NBS e)

The structure of employees by industry is such that $26 \%$ and $23 \%$ of the population are employed in agriculture or in the manufacturing industry, and in these activities twice as many men are employed than women. This is followed by employees in education, health care and public administration employing $5 \%$ to $7 \%$ of the Rasina District population. Women are em- 
ployed three times more than men in the education and health care sector while in public administration this ratio is more uniform. (NBS e)).

The educational structure of the population shows the quality of the workforce, and it is also significant from the consumption aspect, since consumer preferences for certain types of goods and services differ depending on the level of education. The population educational characteristics during the second half of the 20th century indicate a tendency to improve the population educational structure and increase the share of the population with secondary and academic education, while the part of population over age of 60 is related to primary education only.

The educational structure of the Rasina District population is dominated by secondary educated population that makes up $44 \%$ of the total population of the district, followed by the primary educated population (24\%), while academic education and college degree education are present with $7.1 \%$ and $5.3 \%$ of the total Rasina District population, respectively. In addition to such an unfavorable population educational structure, there are also $2.78 \%$ of illiterate persons, most of whom are age over 65 . If we analyze population educational structure by computer literacy, we can observe a large number of computer illiterate persons - 121,405 , which is $50 \%$ of the Rasina District population. All these indicators point to the extremely unfavorable educational structure of the Rasina District population. (NBS e)).

\section{THE IMPORTANCE OF AGRICULTURE AND RURAL AREAS FOR THE DEVELOPMENT OF RASINA DISTRICT}

Economic entities from the processing industry (chemical, machine, wood-processing, textile and food), trade, transport and construction have the greatest influence on the development of Rasina district, as well as the City of Krusevac, and this is confirmed by the fact that they employ about $90 \%$ of total employed population. According to the Business Registers Agency, there were 9,396 business entities registered in Rasina District in 2016, presented by 2,179 companies and 7,217 entrepreneurs. It can be observed that entrepreneurs make up over $75 \%$ of all economic entities of the Rasina District, and their number continues to increase, primarily due to active policy for small and medium-sized enterprises (SME) development measures, which provide subventions and credit lines. There is significant contribution due to the harmonization of the SME Development Strategy with the Small Business Act.

The SME Development Strategy refers to the period 2015-2020 and is part of the strategic framework for the competitiveness development of the Republic of Serbia economy. It draws SME closer to funding, enhances and develops human resources, improves the business environment and access to new markets, with particular attention to promoting, encouraging and developing entrepreneurship for women and young people, as well as social entrepreneurship.

The Small Business Act, adopted by the EU 10 years ago, points to the importance of SME and their major contribution to faster economic development hence SME are necessary to place at the center of political and economic activities. SME need to be leaders of employment and economic growth at the local level, too, because they significantly contribute to the creation of an economic structure that must meet the needs of consumers.

The Regional Chamber of Commerce (RCC) has an important place in the economic development of the Rasina District and the City of Krusevac itself. Through its activities, RCC 
promotes entrepreneurship and SME development, enables the exchange of experiences in the domestic and international environment as well as establishment of business relations and provides expert assistance in the legal regulations interpretation. RCC encourages the exchange of business ideas by organizing seminars, presentations, workshops and conferences. RCC also promotes businessmen by developing profiles of companies (companies and entrepreneurs) and by promoting businesses subjects in the country and abroad, leading to increased exports, mutual businessmen connecting, saving in information and education costs, improving business and competitiveness. In this way RCC contributes to the identification of needs and problems of businessmen, as well as to the implementation of joint actions of the RCC Krusevac, National employment services Krusevac, the Regional Development Agency and local self-governments to eliminate them. Also, great support for SME development comes from the Regional Center for SME Development, which provides advisory and information services, and helps through various specialist trainings for starting a business and developing entrepreneurial spirit, especially for young people. For the last ten years, the Business Incubator has been renting out business premises at preferential prices to the unemployed, individuals and legal entities with good business ideas, and has been helping them through various consulting and entrepreneurial trainings. The role of the Union of Employers and the Association of Entrepreneurs in professional connecting, should not be overlooked, thus contributing to problem solving, but also to networking to exchange experiences and information and to act jointly in the markets.

Economic development SWOT analysis of the City of Krusevac shows that agriculture and rural territory represent extremely important part of this analysis because both the great strengths and the great chances, but also the great weaknesses and threats come from the agriculture sector. Serbia is traditionally an agricultural country, and the same applies to the central part of the country and the Rasina District, which has a favorable geographical position and climatic conditions conducive to diversified agricultural production. The villages have an attractive infrastructure so agriculture is the basis of the processing industry. The opportunity for faster development of agriculture, and thus overall economic development, comes from urban institutions that have adopted a package of incentive measures, as well as from farmers' associations connecting businessmen and farmers, thereby ensuring higher agricultural production, market expansion and better placement. The opportunity must be search in the development of rural tourism and attracting foreign tourists, as there is a significant cultural and historical heritage and conditions for the development of religious and health-recreational tourism. The weaknesses and threats to the development of agriculture are the weaknesses and threats to the overall economic development, which relate to the unfavorable demographic trends and the departure of young and educated personnel to major cities or abroad, as well as the underdeveloped entrepreneurial spirit.

The institutions of the City of Krusevac make great efforts to reduce these disadvantages and threats through a variety of entrepreneurial training for the entrepreneurship development of women (especially women in rural areas), young people and social entrepreneurship. The establishment of the Faculty of Agriculture in Krusevac contributes significantly to this issue. Along with the professional education of young people in the field of animal husbandry, vegetable growing and crop production, fruit growing and viticulture, this academic institution will certainly influence the stay of young people in the rural areas, mitigate the negative demographic trends not only in Krusevac, but in the wider region and provide the application of acquired knowledge in career development in (agro)business and promotion of their own farms. 
Table 4. SWOT analysis of economic development of the City of Krusevac

\begin{tabular}{|c|c|}
\hline Powers & Weaknesses \\
\hline $\begin{array}{l}\text { - Long-standing industrial tradition } \\
\text { - Broken network of business support institutions } \\
\text { - Professional workforce } \\
\text { - Budget funds for the promotion of employment and } \\
\text { agricultural development } \\
\text { - Available farmland } \\
\text { - A large number of livestock farms } \\
\text { - Professional associations in agriculture } \\
\text { - Agriculture as a basis for the development of the } \\
\text { processing industry } \\
\text { - Satisfactory rural infrastructure (electricity, water, } \\
\text { sewage system, telephone, road) } \\
\text { - Opportunities for diversified agricultural production }\end{array}$ & $\begin{array}{l}\text { - Insufficient investment } \\
\text { - There is no free land for investment and } \\
\text { unresolved property relations } \\
\text { - Distance from the highway }(23 \mathrm{~km}) \\
\text { - There are no investor reliefs } \\
\text { - There is no consensus on the directions of } \\
\text { economic development } \\
\text { - Incomplete railway electrification } \\
\text { - Migration of young and educated staff to } \\
\text { major cities and abroad } \\
\text { - Underdeveloped entrepreneurial spirit } \\
\text { - Existing production volume cannot meet } \\
\text { market needs chances }\end{array}$ \\
\hline Chances & Threats \\
\hline $\begin{array}{l}\text { - Workforce in accordance with the demands of the } \\
\text { - Coonomy } \\
\text { - Cooperation with the Diaspora and inclusion in EU funds } \\
\text { - Construction of industrial zones } \\
\text { - Establishment of a more efficient City Administration } \\
\text { - Connecting businessmen and farmers and jointly joining } \\
\text { the market and marketing } \\
\text { - Formation of farmers' associations and raising production } \\
\text { to a higher level } \\
\text { threansion of estates and attraction of foreign tourists } \\
\text { threats }\end{array}$ & $\begin{array}{l}\text { - Unemployment } \\
\text { - Grey economy } \\
\text { - Adverse demographic trends } \\
\text { - Slow economic development } \\
\text { - Incomplete privatization process } \\
\text { - Insufficient inter-institutional cooperation } \\
\text { - Low focus on foreign tourists }\end{array}$ \\
\hline
\end{tabular}

Source: City of Krusevac, Sustainable Development Strategy

Potential basis for greater investments in agricultural production is represented by favorable geographical position and climatic characteristics, fertile agricultural land, good rural infrastructure, existence of geothermal and mineral waters, developed advisory service, favorable agro-ecological conditions and high interest of farmers for the application of modern achievements. The Rasina District stands out for its production of planting materials (fruit, vine, conifers, ornamental shrubs), field crops and vegetable crops, and livestock production (breeding cows, pigs and poultry) has always been significant. Organic production is not sufficiently represented in the Rasina District, although there are conditions for its development. Less than 1\% of the area is under organic production, primarily berries. There are prerequisites for starting, expanding and promoting organic livestock production, especially in mountainous areas.

There are significant advantages in the Rasina District for such production. Above average favorable natural conditions are: ecologically preserved natural environment at the foot of the mountain Kopaonik and Jastrebac, areas under meadows, pastures and forests (Jastrebac is the most forested mountain in the Balkans), clean water and air. However, natural conditions are not sufficient so coordinated activities are needed at all levels, causing multiple results in the demographic context hence it would slow down and to some extent stop the emptying of mountain villages. (Katić et al., 2010, p 250).

The Local Sustainable Development Strategy of the City of Krusevac prioritizes economic development, which is impossible to achieve without attracting investment, agricultural and rural development and tourism development. 
By adopting the Regulation on the allocation of subsidies in agriculture and rural development in 2018, the Republic of Serbia has prescribed incentives for the preparation and implementation of local rural development strategies too, which helps local communities in the implementation of the adopted strategy. (Regulation on the allocation of subsidies in agriculture and rural development in 2018). It implements agricultural and rural development measures aimed at improving the quality of life in rural areas, reducing poverty, sustainable resource management, protecting the environmental and improving the institutional framework for the development of agriculture and rural areas.

The development of agriculture and rural areas is one of the strategic goals of the Sustainable Economic Development Strategy of the City of Krusevac and the specific goals that need to be achieved in order to provide the strategic goal are increasing the productivity and competitiveness of agriculture, diversification of rural economic activities, application of new knowledge and skills as well as improvement of land structure. All of these issues are represented in Table 5.

Increasing the productivity and competitiveness of agriculture can be achieved by stimulating the development of agricultural production (plant and livestock production, as well as the production of planting material), supporting the introduction of new quality standards, supporting the processes of farmers association and strengthening their capacities. This refers to support for the transition from conventional to organic production, support to farms in the processes of implementation and certification of safety and quality systems, as well as increasing the yield of agricultural products by timely control of diseases and pests and by monitoring meteorological indicators, i.e. by building meteorological stations. Support to the processes of farmers association and strengthening of their capacities includes support to agricultural associations, their networking with domestic and foreign agricultural associations, the formation of agro-clusters and the development of agricultural cooperatives. It will be allocated 28.2 million RSD from the city budget to achieve these goals in the period 2010-2020. Donors will participate with 3 million RSD, and farmers themselves with 800 thousand RSD. (City of Krusevac, Sustainable Development Strategy)

The establishment of local partnerships and the creation and implementation of local rural development strategies, contributes to the achievement of sustainable development through the addition of value, improving the rural economy, improving the quality of life, improvement and promotion of natural and cultural heritage, the environment as well as fostering social dialogue of the rural population and the quality management of local resources (National program for agriculture for the period of 2018-2020)

Certain laws have been adopted in the field of agribusiness, but legislation needs to be further improved. International quality standards have significant importance in order to improve and ensure food quality. The involvement of farmers, entrepreneurs, farmers' associations and producers of agricultural products, along with coordination of local and state institutions, is also important for setting strategic goals and for implementing the strategy. (Ristić, 2013, p. 240).

The City of Krusevac, the Agricultural Office of the City of Krusevac, the Institute of Forage Crops Krusevac, the Agricultural Expert Service of Krusevac, the Regional Center for Rural Development and the Regional Center for SME participate in these activities. The aim of these measures is to increase production and quality of agricultural products, to increase supply to the domestic market and to export, with more efficient use of resources and reduction of production costs, which would also increase the economic effects. 
Table 5. Vision, mission and goals of economic development of Krusevac city

\begin{tabular}{|c|c|c|}
\hline $\begin{array}{l}\text { PRIORITY } \\
\text { VISION }\end{array}$ & STRATEGIC GOALS & SPECIFIC OBJECTIVES \\
\hline \multirow{10}{*}{$\begin{array}{l}\text { PRIORITY: } \\
\text { Economic development } \\
\text { VISION: } \\
\text { Krusevac as business, } \\
\text { industrial and } \\
\text { agricultural center, } \\
\text { attractive for work, life } \\
\text { and investments }\end{array}$} & $\begin{array}{l}\text { Supporting the economy } \\
\text { and entrepreneurship }\end{array}$ & $\begin{array}{l}\text { Strengthening competitiveness and improving the } \\
\text { business environment }\end{array}$ \\
\hline & Attracting investments & $\begin{array}{l}\text { Providing an adequate location with adequate } \\
\text { infrastructure and promoting the development } \\
\text { possibilities of the Krusevac City }\end{array}$ \\
\hline & \multirow{4}{*}{$\begin{array}{l}\text { Development of } \\
\text { agriculture } \\
\text { and villages }\end{array}$} & $\begin{array}{l}\text { Increasing agricultural productivity and } \\
\text { competitiveness }\end{array}$ \\
\hline & & Diversification of rural economic activities \\
\hline & & Applying new knowledge and skills \\
\hline & & Improvement of land structure \\
\hline & \multirow[t]{4}{*}{ Tourism development } & Tourism development to conserve natural resources \\
\hline & & $\begin{array}{l}\text { Education and improvement of conditions for tourism } \\
\text { development, stimulation of interest of entrepreneurs } \\
\text { and rural households }\end{array}$ \\
\hline & & $\begin{array}{l}\text { Improving the quality of tourist facilities, integrating } \\
\text { tourist, educational, hospitality, trade, service and } \\
\text { production activities }\end{array}$ \\
\hline & & $\begin{array}{l}\text { Using modern communication, management and } \\
\text { marketing }\end{array}$ \\
\hline
\end{tabular}

Source: City of Krusevac, Sustainable Development Strategy

Activities and measures for the advancement of agricultural production are conducted by the Agricultural Advisory Expert Service since its forming 1900 to these days, implementing the work of special services (animal husbandry, fruit and wine growing service, crop growing service, crop protection service, agroeconomics, testing laboratory and agricultural pharmacy). Counseling is carried out in cooperation with farmers, through various forums, workshops, visits, consultations, lectures. Practice shows that counseling produces better results if the real problems of agricultural producers are taken into account. The active farmers participation in the development of plans for the agriculture improvement and their mutually work with advisers to identify and understand existing problems is necessary, because in addition to identifying problems, the potentials, goals and measures needed to overcome them are determined. (Miladinović, 2007, pp 289-293).

Agricultural advisory expert service encourages agricultural production development undertaking a wide range of measures and activities, which contribute implementation of Local Economic Development Strategy: gives notices of calls for proposals for stimulating funds awarded by the Budgetary Fund for the Development of Agriculture, Entrepreneurship and SME of the City of Krusevac and the Ministry of Agriculture, Forestry and Water Management, monitors the implementation of agricultural production loans granted by commercial banks whose interest and credit processing costs have been paid by the city, organizes and implements an agricultural fair and agricultural exhibitions, organizes professional lectures and study tours in order to learn about good practices examples, encourages and helps the development of cooperatives, monitors the occurrence of plant and animal diseases, provides information on the realization of autumn sowing and harvesting, and on the preparation for the spring harvest and produces a promotional materials due to affirmation of rural potential development (City of Krusevac, Department for Agriculture).

Diversification of rural economic activities includes activities to support capacity building for processing and packaging of agricultural products, marketing support and promotion of agricultural and other agricultural products, and establishment of business incubators in villages in order 
to identify and support activities that can generate income in rural areas. These activities are attended by the Institute of Forage Crops Krusevac, the City of Krusevac, the Agricultural Office of the City of Krusevac, the Agricultural Expert Service Krusevac, the Regional Center for Rural Development and the Krusevac Tourist Organization. The city earmarked 18 million RSD from the budget, donors 13 million RSD and farmers themselves 3 million RSD for this purpose (City of Krusevac, Sustainable Development Strategy). The aim of these measures is to achieve positive economic effects through modernization of production capacities and promotions of marketing.

The application of new knowledge and skills as a specific objective will be realized through holding seminars and demonstrating workshops aimed at improving all areas of agricultural production, introducing experts and advanced farmers with new technologies through seminars, fairs, exhibitions. Also, there will be involve building and strengthening local capacities for the preparation of projects initiated by national and international organizations, formation and organization of rural business and management schools and innovation centers in the City of Krusevac. The city has earmarked 26 million RSD for these activities, 9 million will be provided from donors, and farmers will participate with 4 million RSD. (City of Krusevac, Sustainable Development Strategy). Improving management wants to improve production and increase positive economic effects.

Agricultural producers themselves have a significant role in the realization of the goals and since they will be helped by the state and the city, should slowly realize transition from a traditional peasant household to a modern, economically viable agricultural holding. This transition begins with creating the optimum size of estates, because in agriculture, fruit growing and viticulture there is a need for large areas, using machinery and employing entire families. Opposite to this, the production of vegetables, flowers and livestock does not require such large areas, but requires great knowledge, motivation and secure placement. Certainly, it is necessary to act on the consolidation of estates, which is an opportunity for the agriculture of the Rasina District, but also for agriculture in Serbia, with the assistance of the local level administration, banks and the state, of course (Adžić, 2007, pp.31-32.).

Improvement of land structure as the fourth specific objective of agricultural and rural development is realized through ameliorative measures of land repair in order to preserve the fertility of agricultural land, through activities to improve anti-hail protection, construction and arrangement of field roads, protection of land from floods, torrents and erosion, as well as incentives for consolidation agricultural land.

Particular attention is paid to changing the agricultural land cultivation, the use of agricultural land, the exploitation of mineral, raw materials (clay, sand, pebbles, peat, etc.), the use of agricultural land, the use of arable agricultural land for non-agricultural purposes, in the case of raising forests, artificial meadows and pastures, as well as the protection, use and improvement of agricultural land.

Carriers of these activities are the Institute of Forage Crops Krusevac, the Agricultural Expert Service of Krusevac, the City of Krusevac, the Office of Agriculture of the City of Krusevac, the Regional Center for Rural Development, the Ministry of Agriculture, Forestry and Water Management, the Directorate of Urban Planning of Krusevac and the Public Utility Company of Serbia. The funds are provided from the budget of the city and the Ministry of Agriculture, Forestry and Water Management. These activities will contribute to the expansion of arable land and the preservation and increase of fertility of the land and irrigated area. 
Long-term directions of Rasina region agriculture development are in accordance with the Strategy for Agriculture and Rural Development of the Republic of Serbia: the establishment of a market economy, increasing the profitability of agriculture and concern about the rural areas development (Law on Agriculture and Rural Development, Article 4).

\section{ECONOMIC DEVELOPMENT OF RASINA DISTRICT AND TOURISM}

In addition to rural development, respecting agriculture and village development, tourism development presents important strategic goal in the Sustainable Development Strategy of the City of Krusevac. Achieving this goal would ensure the conservation of the exceptional natural resources of this region, although development requires the education of entrepreneurs and rural households to increase the quality of tourism facilities. Linking agriculture and tourism, integrating service, tourism, hospitality, educational and commercial activities and following contemporary trends in marketing, management and communications, would certainly lead to the improvement of tourism.

Rural tourism is of particular importance for the development of agribusiness systems, as a spectrum of activities, services and additional facilities offered to tourists in rural areas where agricultural production takes place at the same time. Tourism on family farms can attract more tourists and generate additional income for the farm. This tourist product must be based on the principles of sustainability and non-mass supply; therefore, tourists should be offered specific elements of the rural environment, traditional hospitality and the lifeway values of the local population. Rasina District, the City of Krusevac, as well as whole Serbia have significant potential for the development of this tourist product, due to its preserved nature, tradition, cultural and historical values. Rural tourism should be based on rural experiences in rural areas, with full affirmation of activities such as: agritourism / rural household - farm, outdoor activities, eco-tourism and combined forms of tourism. Rural tourism in the Rasina District should be promoted in both the domestic and foreign markets, with a particular focus on the target market for tourists from major cities. At the same time, promotion should also be realized in foreign markets that already have a developed interest in rural experiences, such as: Great Britain, Germany, France, Italy, Austria, Hungary, etc. The richness, conservation and attractiveness of natural resources, the large number of traditional agricultural households and the growing interest of the international market in rural tourism experiences indicate great potential for the development of rural tourism in both Serbia and the Rasina District. In this regard, better infrastructure in rural areas and the inclusion of the organic food concept in the tourist offer would be extremely important (Babić, Stojiljković, 2016, p.451).

Natural resource conservation activities are carried out through projects of access control to tourist sites, construction of parking spaces, construction of bicycle and pedestrian paths, installation of tourist signposts and signage, equipping of Churches and monasteries with necessary accompanying equipment and cleaning and landscaping of beaches and bathing areas. The leaders of these activities are the City Administration, the Directorate for Urbanism and Construction, the Business Center, the Tourist Organization of the City of Krusevac, the line ministries, the local communities and the Institute for the Protection of Monuments.

Improving the services quality in the tourism sector is carried out through activities of continuing education on rural tourism and raising awareness of the tourism importance as a strategic economic branch. Organizing workshops on old crafts, customs and traditions, preparing and 
serving traditional dishes, organizing promotions and study trips in at home and abroad are some of these activities, too. Carriers of these activities are the City Tourism Organization, City Administration, Ethno Restaurants, Rural Women's Association, Local Tourism Organizations in the City, Office for Local Economic Development, Local Television Stations, Agricultural Expert Service of Krusevac, Cultural Education Community and the Department of Finance, Economy and Ecology.

Increasing the quality of tourist facilities along with combining service, tourism, hospitality, educational and commercial activities is carried out by increasing the hotel offer (spa, fitness, wellness, congress), increasing the quality of accommodation facilities, such as houses, pensions, apartments. Souvenir production with city symbols, placement of healthy organic food through tourism offerings, construction and improvement of accommodation capacities in monastery residences and connection with Orthodox centers in Greece, Russia, Bulgaria, Macedonia, Montenegro and Republika Srpska, should be include too, as well as tourism connecting with agriculture and other economic branches and development of entrepreneurship and entrepreneurial ideas. The leaders of these activities are the Tourist Organization of the City of Krusevac and the City Administration, with the cooperation of partners such as interested individuals, hotels, restaurants and other catering establishments, agricultural farms, organic food producers, local communities and religious communities.

Monitoring of modern trends in marketing, management and communications is necessary to connect different types of tourism - rural, religious, recreational, wine, health, cultural, gastronomic, excursion, manifestation, congress tourism - and can be realized through the creation of web sites, portals and services, promotional material and movies. Such use of internet technologies contributes to better promotion of tourist potentials and better approaching of tourist events and contents to potential domestic and foreign tourists, as well as active participation of the local population in the tourist economy. In this context, development and improvement of the ,year-round" tourist destination is relevant, too.

All these activities that contribute to the development of tourism are financed from the republican and city budget.

In order to provide support to SME in the field of agribusiness and tourism development, entrepreneurs of the Rasina District, as well as all entrepreneurs in the Republic of Serbia, are provided with the funds of the Development Fund and programs for encouraging entrepreneurship. Entrepreneurs can get at least 75.000 RSD of grants and legal entities - at least 250.000 RSD, while the largest amount of grants for all businesses is 12,5 million RSD. For legal entities, the repayment period of these loans is up to 10 years with a grace period of one year and up to 8 years. Entrepreneurs are also provided with a grace period of one year and the repayment period cannot be less than 2 years. The interest rate is $1 \%$ per annum, with a bank guarantee, or $2 \%$ per annum, if other means of securing the loan are used. (Development Fund of the Republic of Serbia)

The Chamber of Commerce of the Rasina District, in cooperation with the Offices for Local Economic Development in the Rasina District municipalities and the Republic Agency for Development of SME, provides special credit lines to small and medium-sized enterprises. One such support is the Italian Credit Line Program opened in 2016 and will be close in 2022. The interest rate is $4.35 \%$ per annum, repayment is made in semi-annual installments, with a grace 
period of 2 years, and the loan amount is from 5 thousand to 1 million euros for entrepreneurs and micro enterprises, and from 50 thousand to 1 million euros for small and medium-sized enterprises. Conditionally, $70 \%$ of the loan have to be used to purchase equipment, techniques and technology of Italian origin, certified to be Italian products by the Italian Chamber of Commerce. The equipment, technique and technology purchased in this way are exempt from value added tax (VAT). The program includes Bank Intesa, Halk Bank, Komercijalna Banka and Unicredit Bank. (SDA)

Providing tourism services at individual farms not only provides additional income for the farm but also contributes to agricultural development and tourism development. In addition to traditional agricultural products, guests should also be offered elements with local environment and local population characteristics.

The great potential for the development of rural tourism in Serbia, therefore in the Rasina District, comes from the growing interest of farms in providing such services, as well as the growing interest of the international market in demanding these services. In addition to the activities predicted and implemented by the Sustainable Development Strategy of the City of Krusevac, introducing organic food into the tourist offer, using the internet for online bookings and the many benefits provided by social networks, traditionally with modern and contemporary can be combined and thus contribute to the development of agribusiness and tourism. The tourism industry has thus become highly dependent on global networks and the Internet, which contribute significantly to the realization of economic effects. (Vujović et al., 2012, p 55). All of these require numerous improvements, changes and restructurings, as well as significant financial resources and cooperation of all relevant actors - from the level of the individual agricultural farms and local institutions to the state level.

The city of Krusevac has been categorized as a tourist destination of the second category, with all the necessary prerequisites to become an exceptionally attractive tourist destination, in accordance with the Law of Tourism and Tourism Strategy of the Republic of Serbia in the period from 2016 to 2025. The City of Krusevac adopted the Program for Tourism Development of the city of Krusevac for period 2019-2024 which provides a concrete proposals and directives to the all tourism acters from the City of Krusevac area in order to advance activities in tourism domain. This should increase the competitiveness of the tourism economy and ensure the visibility of the city of Krusevac at the Serbia tourist map (The City of Krusevac, Program for Tourism Development of the City of Krusevac 2019-2024) hence the main goals are:

- sustainable economic and ecological development of tourism in the City of Krusevac,

- strengthening the competitiveness of the tourism industry and related activities in the domestic, regional and international markets,

- increasing the share of the tourism sector in the gross domestic product of the City of Krusevac,

- increase in the number of employees in the tourism sector and their participation in the structure of the employees total number in the City of Krusevac,

- creating an image of the City of Krusevac as an attractive competitive tourist destination, and

- long-term protection of natural and cultural resources in the function of tourism. 
Table 6. Tourist economy of Krusevac, 2017

\begin{tabular}{|c|c|c|c|c|c|c|c|c|}
\hline \multirow{2}{*}{$\begin{array}{c}\text { Tourist and } \\
\text { catering } \\
\text { facilities }\end{array}$} & \multicolumn{2}{|c|}{$\begin{array}{c}\text { Accommodation } \\
\text { capacities }\end{array}$} & \multicolumn{3}{|c|}{ Tourist arrivals } & \multicolumn{3}{c|}{ Tourist nights } \\
\cline { 2 - 9 } & Rooms & Beds & Total & Domestic & Foreign & Total & Domestic & Foreign \\
\hline 5.678 & 219 & 464 & 25.443 & 19.216 & 6.227 & 96.465 & 82.601 & 13.864 \\
\hline
\end{tabular}

Source: City of Krusevac, Tourism Development Program of the City of Krusevac 2019 - 2024.

In total, 5.678 companies were engaged in tourism and catering (with accommodation capacity of 219 rooms, with a total of 464 beds) at City of Kruševac Territory, In 2017 (December, 31) During 2017, Krusevac was visited by over 25 thousand tourists and over 96 thousand overnight stays were realized by domestic and foreign tourists. This is a $22 \%$ increase in tourists number and a 14\% increase in overnight stays, compared to 2016. (City of Krusevac, Tourism Development Program of the City of Krusevac 2019 - 2024.) The average length of stay for domestic tourists is 4 days, for foreign tourists 2 days.

The City of Krusevac offers the following tourist products to tourists:

- Short City breaks, cultural and historical tourism, health tourism (wellness and spa programs at the Ribarska Banja Spa) and religious tourism - which represent tourism products of the first category; these products have already positioned themselves in the market and for which it is realistic that they can be further developed and commercialized in the next five years,

- Manifestation tourism (Balloon festival "Kruševac kroz oblake", International festival "Viteški megdan u Lazarevom gradu", Medieval wedding in the Church of Lazarica, International Festival of Humor and satire "Zlatna kaciga", Vidovdan Children's Carnival, Vidovdan Souvenir Fair, Motocross championship, International Festival of Orthodox Movie "Snažni duhom", "Belovodska rozeta", "Kulturno leto" in Ribarska Banja Spa), active vacation (fishing, hunting, hiking, cycling) and sports and recreational tourism (football stadium, indoor and outdoor swimming pools, tennis courts, outdoor athletic - soccer block) - which represent tourist products of II category, currently having a specific position on the market, but require longer period development, and

- Tourism products of the third category (business, rural and educational tourism) having potential for development, but it is currently not developed adequately.

Rural tourism is a specific type of tourism that attracts tourists interested in rural culture with its nature, in learning about the traditions and countryside lifestyle and the quality of the environment. Environmental issues, such as protection, preservation and improvement of the environment, are given special attention, which is reflected in numerous programs, funds and incentives for agricultural producers and other economic entities that conserve the environment. Ecologically responsible behavior is of great importance for the Republic of Serbia as well, since ecological and economic sustainability are important prerequisites for the reconstruction and development of rural areas. (Djekić et al., 2011, p 51). The City of Krusevac with a favorable geographical position and a large number of villages has extremely advantageous opportunities for rural tourism development, which is recognized in the Sustainable Development Strategy of the city of Krusevac and in the Tourism Development Program of the City of Krusevac 2019-2024. The benefits and opportunities for the development of rural tourism are particularly pronounced in the villages towards Ribarska Banja Spa or the villages on the slopes of Jastrebac Mountain as well as in the villages by the side of the Morava River and the Lake Celije. 
The City of Krusevac tourist organization, in cooperation with the City Administration, has issued a „Guide to the implementation of domestic homecraft categorization ,, to keep potential hosts informed about the elements of rural tourism. Intensive work is being done to educate the local population regarding to point out the economic justification for dealing with this type of tourism. Lectures are organized in the villages, on the topic of encouraging the development of rural tourism and improving the quality of tourist offer, all with the aim of increasing the number of registered rural households engaged in rural tourism and maintaining and improving the quality of their services.

Rural tourism is a necessary component of sustainable environmental development, of the tourism economy, but of the overall economy, too. That is why it is necessary to use existing natural resources. In the presence of the exposed natural environment, tourists have the opportunity for walking, recreation, excursions to the monastery and other cultural and historical monuments, the possibility of seasonal hunting and fishing, picking forest fruits and herbs. Better use of existing natural resources for the development of rural tourism is contributed by: continuous training of the local population in accordance with the leading trends of rural tourism; continuous contact with existing and potential rural tourist households; investment in rural infrastructure; standardization of services; categorization of rural households and existing private accommodation in the rural area; continuous quality improvement of existing and introduction of new services in the countryside; formation of a specific tourist product and offers of rural tourism households; marketing placing on the domestic and international markets; improving manifestation rural tourism. So far, two "Fair Tourism, Healthy and Natural Creativity" fairs have been organized with the intention of maintaining each year in a different village.

Insufficient tourism revenues, lack of a clearly defined tourism brand, insufficient accommodation capacity, lack of financial resources for tourism development, underutilization of available EU funds and favorable loans from the Ministry of Tourism, youth motivation to stay in the countryside, problems in the development of rural tourism (old population and the lack of a younger population to stay in the countryside), the presence of a grey economy in the area of housing services and the insufficient commercialization of cultural and historical heritage and tradition are just some of the problems and weaknesses of the tourism economy of the City of Krusevac. Continuous planning, organizing, leading and control of all activities could transform these weaknesses to become strengths, advantages, chances and opportunities, which would shape the city of Krusevac as a recognizable competitive tourism destination, contributing to the image of the city in a wider environment.

\section{CONCLUSION}

Agriculture is a traditional activity in Serbia, especially in those regions where there are natural conditions and benefits for its development, which is the case in the Rasina District. Geographical location, relief and land features, favorable climatic conditions, cultural and historical heritage and human resources are potentials that can be used for the development of the agricultural activity itself, but also for faster economic development of this region.

An important direction for the future development of agriculture is the preservation and optimal use of available natural resources, increasing the volume of agricultural production, changing the production structure in favor of production forms intended for export, production of high quality products of processing higher stages, production of food and beverages in accordance 
with the requests of the tourism economy. The aim of such development concept is to settle domestic demand of the population and tourists, industrial processing and export of agricultural food products. Agricultural development must focus on the modernization and change of production structure, in the direction of greater market orientation, cost efficiency and the implementation of healthier, so-called „Clean production technologies”.

Rural tourism, as a form of non-mass tourism that most links agriculture and tourism, should be encouraged on small family farms, with the aim of attracting tourists through the preservation of tradition conveniently combined with the necessary modern elements, and generating additional income for rural tourist households. This tourism product must be based on the principles of sustainability, in order to permanently provide adequate content to tourists, respectively to true traditional elements of the rural environment, such as the pure nature, traditional hospitality and lifestyle values of the local population. It is understood that these traditional elements need to be combined with modern amenities (due to the demands of tourists), which do not disturb the rural environment. The richness, conservation and attractiveness of natural resources, the large number of traditional agricultural households and the growing interest of the international market in rural tourism experiences indicate great potential for the development of rural tourism in the Republic of Serbia as well as in the Rasina District. In addition to the necessary restructuring, important for agricultural and tourism development (in line with EU recommendations), emphasis should also be placed on improving rural infrastructure and integration of organic agricultural production into the agricultural production structure and rural areas tourism supply.

As economic development is one of the priorities in the Sustainable Development Strategy of the City of Krusevac, so the development of agriculture and villages is one of the strategic goals of economic development, supporting economy and entrepreneurship, attracting investments and tourism development. In order to develop agriculture and rural areas, activities have been implemented to increase the productivity and competitiveness of agriculture, to diversify rural economic activities, to apply new knowledge and skills, and to improve the land structure. These activities involve the City Administration, local city institutions, small and medium-sized enterprises, entrepreneurs, farmers themselves and line ministries, therefore cooperation of all levels participants and joint financing ensure the successful realization of the predicted activities. There are preconditions for the development of rural tourism, especially if other types of tourism (religious, health, excursion) can be realized, and connection of tourism and agriculture could achieve remarkable results. Demand for such services is on the rise, the interest of individual farms for the providing of these services, is increasing, too, by improving the production of healthy organic food the quality of services also would be increased, which would lead to better overall results, not only agriculture and rural development and tourism, but also overall economic development of the region.

City of Krusevac has recognized the potential for the development of agriculture, villages and tourism, therefore the economic development of the city and the region are based on them. By implementing various measures and activities carried out by the City of Krusevac and local regional institutions, significant development of agriculture and tourism is achieved. These activities are in line with the activities implemented at the state level so significant funds from the budget are allocated to them. Regardless of the natural advantages, the problem of Serbian agriculture, including Rasina region agricultural too, is the unfavorable age and ownership structure, as well as insufficient knowledge of marketing, economy and ecology. Large investments, a close approaching to export standards and increasing competitiveness are needed in order for agricultural production to be the backbone of rural development. 


\section{REFERENCES}

Adžić S., (2007), How to complete the transition in the agro-industrial complex? A case study for Vojvodina, Transition, vol.9. No 19-20, p 21-48.

Babić V., Stojiljković M., (2016), Development of agribusiness in tourism of Rasina district, 1st International Thematic Monograph: Modern Management Tools and Economy of Tourism Sector in Present Era, Belgrade: Association of Economists and Managers of the Balkans with Faculty of Tourism and Hospitality, Ohrid, North Macedonia, p 442-456.

Djekić, S., Jovanović, S., Krstić, B., (2011), Some Determinants of Sustainable Rural Development Policy and Strategy - Agricultural and Rural Policy in Serbia - Necessity to Speed Up Reforms (str.49-65). Belgrade, Serbia: DAES. Novi Sad, Serbia: Faculty of Economics, University of Novi Sad

Katić, B., Savić, M., Popović V. (2010), Organic livestock production - an unused chance of Serbia, Agricultural Economics Number 2/2010, p 245-255.

Miladinović M. (2007), A Rural Sociological Approach to Planning in Counseling, Economics of agriculture 2/2007, p 287-300.

Ristić, L. (2013), Strategic management of sustainable rural development in the Republic of Serbia, Economic horizons, 15(3), p 229-243, Faculty of Economics Kragujevac

Vujović, S., Cvijanović, D., Štetić, S. (2012), Destination concept of tourism development, Belgrade: IEP

Law on Agriculture and Rural Development (,Sl. glasnik RS”, 41/2009, 10/2013 - law 101/2016)

Regulation on the allocation of incentives in agriculture and rural development in 2018 (,Sl. glasnik RS”, 18/2018, 66/2018, 86/2018 and 93/2018)

Development Fund of the Republic of Serbia, Program for encouraging entrepreneurship through development projects in 2019 (https://fondzarazvoj.gov.rs/download/E9OMZS2 Program_podsticanja_preduzetnistva_kroz_razvojne_projekte_u_2019._godini.pdf, (25.10.2019.)

NZS - National Employment Service - Monthly statistical bulletin http://www.nsz.gov.rs/live/digitalAssets/10/10892_bilten_nsz_08_2018_-_broj_192.pdf (25.10.2019.)

City of Krusevac, Republic of Serbia - Sustainable Development Strategy of the City of Krusevac 2010-2020.

https://www.krusevac.rs/sr_cir/lokalna-samouprava/vazeci-gradski-propisi/usvojene-strategije/379-strategija-odrzivog-razvoja.html/ (25.10.2019.)

City of Krusevac, Department for Agriculture https://www.krusevac.rs/sr_cir/privreda/poljoprivreda/sluzba-za-poljoprivredu.html/ (25.10.2019.)

City of Krusevac, Tourism Development Program of the City of Krusevac 2019-2024. https://www.krusevac.rs/images/stories/strategije/program\%20razvoja\%20turizma\%20 grada $\% 20$ Krusevca/Program\%20razvoja\%20turizma\%20grada\%20Krusevca.pdf/ (25.10.2019.)

National Agriculture Program 2018-2020. year

(subvencije.rs/wp-content/uploads/2018/01/Nacionalni-program-za-poljoprivredu-za-period-2018-2020.pdf, accessed 25.10.2019.)

RCC Krusevac - Regional Chamber of Commerce of the Rasina Administrative District http://www.privredarasinskogokruga.rs/page/Rasinski_upravni_okrug/(25.10.2019.)

NBS - National Bureau of Statistics

a) Comparative survey of residents 1948.,1953.,1961.,1971.,1981.,1991., 2002., and 2011. 
http://www.stat.gov.rs/oblasti /popis/popis-2011/popisni-podaci-eksel-tabele/ (25.10.2019.)

b) Demographic statistics 2002-2003. http://publikacije.stat.gov.rs/G2006/Pdf/G20064001.pdf (25.10.2019.)

c) Average age by gender

http://data.stat.gov.rs/Home/Result/180708?languageCode=sr-Latn (25.10.2019.)

d) Registered employment by municipality of labor

http://data.stat.gov.rs/Home/Result/240204?languageCode=sr-Latn (25.10.2019.)

e) Labor Force Survey in the Republic of Serbia, 2018.

http://publikacije.stat.gov.rs/G2019/Pdf/G20195646.pdf(25.10.2019.)

SDA - Serbian Development Agency

https://ras.gov.rs/zatvoreni-programi-konkursi/program-podrske-privrednicima-kroz-italijansku-kreditnu-liniju (25.10.2019.) 